\title{
Short-term feeding response of the scallop Argopecten purpuratus exposed to two different diets
}

\author{
Jorge M. Navarro**, María José Fernández-Reiriz ${ }^{\dagger}$ and Uxio Labarta ${ }^{\dagger}$ \\ *Instituto de Biología Marina "Dr. Jürgen Winter”, Universidad Austral de Chile (UACH), Casilla 567, Valdivia, Chile. \\ ${ }^{\dagger}$ Consejo Superior de Investigaciones Científicas (CSIC), Instituto de Investigaciones Marinas, Eduardo Cabello 6, 36208, Spain. \\ ${ }^{\ddagger}$ Corresponding author, e-mail: jnavarro@uach.cl
}

\begin{abstract}
Argopecten purpuratus was exposed to two different diets which reflected short term variations in quantity and quality of the natural food supply typical in bays of southern Chile. No significant differences of clearance rate were observed over different time periods at either of two food concentrations. The scallop reduced its clearance rate significantly when it was exposed to the higher food concentration. Pseudofaeces production occurred only at this high diet and the time factor had no significant effect on this process. The organic content of pseudofaeces was significantly lower than the organic content of the food, suggesting a pre-ingestive selection mechanism. Based on this capacity for particle selection, A. purpuratus was able to compensate for the differences in food quality of the experimental diets and ingesting particulate material containing 38\% organic matter as a result of the selection process when fed at the higher food concentration. Absorption efficiency was lower following exposure to the high food concentration, suggesting that the experimental time of $72 \mathrm{~h}$ was not sufficient to acclimate the digestive response to a food supply significantly different from that of its habitat of origin. Phytoplankton form the principal nutritional source for this epibenthic species, and resuspended detritus, although occurring in large quantities, may only be of importance once digestive processes become acclimated to processing them.
\end{abstract}

\section{INTRODUCTION}

Filter-feeding bivalve molluscs typically experience broad fluctuations in quantity and quality of suspended particulate matter. These fluctuations may be due to biological events such as plankton blooms or to physical events such as the resuspension of bottom sediments by wave action or import of terrigenous sediments caused by rain. Under these conditions, these bivalves may demonstrate various strategies for adapting to the changes in the seston. Upon increase in seston concentrations, the bivalves may avoid saturation of the digestive system by regulating ingestion either by reducing filtering activity, or eliminating excess material in the form of pseudofaeces. Iglesias et al. (1992) showed that bivalve filter feeders have the capacity to compensate adverse environmental conditions (e.g. reduction in the quality of the food supply) by means of physiological mechanisms which permit optimization of the energy gain in habitats characterized by large fluctuations in quantity and composition of seston. Kiørboe \& Møhlenberg (1981), and Ward \& MacDonald (1996), among others, have described capacities of different species of bivalves in preferentially ingesting organic particles from filtered material, and selectively eliminating inorganic material as pseudofaeces. According to these authors this behaviour represents a physiological mechanism to compensate for the dilution of the organic matter by the inorganic fraction of the seston. Behavioural responses and physiological compensations resultant from changes in the environmental food supply are important elements in understanding the suspension feeding process.

The feeding response of $A$. purpuratus was observed when exposed to an unfamiliar environment simulating large fluctuations in available food caused primarily by bio- logical processes including primary productivity and by short-term physical factors such as the resuspension of sediments from the bottom due to tidal action and terrigenous inputs occurring during rainy periods. The acute feeding response of $A$. purpuratus was observed in relation to short acclimation periods $(24 \mathrm{~h}, 72 \mathrm{~h}$ ), with exposure to two different diets which reflected short term variations in quantity and quality of the natural food supply recorded in bays of southern Chile.

\section{MATERIALS AND METHODS}

\section{Experimental conditions}

Individuals of Argopecten purpuratus measuring 50 to $60 \mathrm{~mm}$ in shell length $(1.30-2.42 \mathrm{~g}$ dry tissue weight) were obtained from lantern culture at Hueihue, Chiloé, southern Chile. They were transported to the laboratory for acclimation to standard conditions for seven days prior physiological measurements. Twenty individuals were maintained in each aquarium containing $30 \mathrm{l}$ of seawater at $15^{\circ} \mathrm{C}$ and $30 \mathrm{psu}$ salinity, with water changed every $48 \mathrm{~h}$. The scallops were fed continuously with $3.93 \mathrm{mg} \mathrm{l}^{-1}$ of laboratory cultured Isochrysis galbana.

The feeding behaviour of $A$. purpuratus was determined after acclimation periods of 24 and $72 \mathrm{~h}$. Two diets were used, including one which was below the threshold of pseudofaeces production by the scallops (low diet $=3.93 \mathrm{mg} \mathrm{l}^{-1}$ ) with high organic content $(42.5 \%)$. The second diet was above the threshold of pseudofaeces production (high diet $\left.=20.8 \mathrm{mgl}^{-1}\right)$, with low organic content $(26 \%)$. These diets were prepared by mixing Isochrysis galbana cells with natural sediment collected from the tidal flat at Yaldad, also located in the Chiloé area, and passed through a 
$40-\mu \mathrm{m}$ mesh screen. Total particulate matter (TPM) and particulate organic matter (POM) were determined in dietary samples by filtering three replicate samples of known volume onto weighed glass fibre filters, followed by weighing and ashing (Strickland \& Parsons, 1972).

\section{Clearance and filtration rates}

Measurements were carried out individually on eight scallops maintained in a static system, and clearance rates (CRs) calculated on several measurements (8-10). One additional aquarium without scallops was used as control. Filtration rate was calculated as the product of clearance rate and particle concentration. Below the threshold of pseudofaeces production filtration rate is equal to ingestion rate, and above this threshold filtration rate represents the sum of ingested matter plus rejected pseudofaeces (Velasco \& Navarro, 2002). The total filtration rate (TFR) and organic filtration rate (OFR) were obtained using the following formulas:

$\operatorname{TFR}\left(\mathrm{mg} \mathrm{h}^{-1}\right)=\mathrm{CR} * \mathrm{TPM}$
$\operatorname{OFR}\left(\mathrm{mg} \mathrm{h}^{-1}\right)=\mathrm{CR} * \mathrm{POM}$

\section{Ingestion rates}

Total (TIRs) and organic ingestion rates (OIRs) were calculated multiplying GR by the total weight or by the organic fraction of the diet when these were below the threshold of pseudofaeces production. Above this threshold, TIR was calculated by subtracting the corresponding rejected material (RR) from the respective TFR. Scallops have the ability to select and ingest organic material from a mixed diet, rejecting inorganic materials at food levels above the threshold of pseudofaeces production (Bayne \& Hawkins, 1990). Taking this into account, the OIR was corrected in accordance with the percentage of selection efficiency obtained.

\section{Pseudofaeces production}

Faecal pellets produced by individual scallops were quantitatively collected using a micropipette and filtered off onto glass fibre filters. Total amounts (RR: $\mathrm{mgh}^{-1}$ ) and organic matter fractions (ORR $\mathrm{mgh}^{-1}$ ) of the pseudofaeces were determined as described above in determinations on the experimental diets. Above the threshold of pseudofaeces production the pre-ingestive selection efficiency was calculated following Bayne \& Hawkins (1990), for which it was necessary to determine the organic content of the food (f) and of the pseudofaeces (p) using the following formula:

$\mathrm{SE}=1-(\mathrm{p} / \mathrm{f})$

where $\mathrm{SE}=0$ when $\mathrm{f}=\mathrm{p}$ (no selection), and when $\mathrm{SE}=1$, there is complete selection and ingestion of organic particles from the seston.

\section{Absorption efficiency}

At the end of each experiment the faeces were collected, and subsequently assayed for organic content. Below the threshold level for pseudofaeces production (low diet), the absorption efficiency was determined based on the organic content of the diet. Above the threshold of pseudofaeces production (high diet), since $A$. purpuratus has the ability to select organic matter, the absorption efficiency was estimated using the organic content of the ingested food and that of the faeces. Conover's (1966) method was used to determine absorption efficiencies and the absorption rate was calculated as a product of the organic ingestion rate and the absorption efficiency.

\section{Standardization and transformation of variables}

The experimental scallops were dissected and soft tissues were dried at $70^{\circ} \mathrm{C}$ for $48 \mathrm{~h}$, after which the remains were individually weighed. Due to the differences in the dry tissue masses among the experimental animals, the physiological rates were standardized per gram dry tissue weight following the formula of Bayne et al. (1987):

$\mathrm{Y}_{\mathrm{s}}=\left(\mathrm{W}_{\mathrm{s}} / \mathrm{W}_{\mathrm{e}}\right)^{\mathrm{b}} \mathrm{Y}_{\mathrm{e}}$

where: $Y_{\mathrm{s}}=$ the physiological rate for an animal of standard weight, $\mathrm{W}_{\mathrm{s}}=$ the standard weight of the animal, $\mathrm{W}_{\mathrm{e}}=$ the observed weight of the animal, $\mathrm{Y}_{\mathrm{e}}=$ uncorrected (measured) physiological rate, $\mathrm{b}=$ the weight exponent for the physiological rate function.

Table 1. Argopecten purpuratus. Physiological variables measured in relation to time and food quantity.

\begin{tabular}{|c|c|c|c|c|c|c|c|c|c|c|c|c|}
\hline \multirow{2}{*}{$\begin{array}{l}\text { Time } \\
\text { (h) }\end{array}$} & \multirow[b]{2}{*}{$\begin{array}{c}\text { Diet } \\
\left(\mathrm{mg} \mathrm{l}^{-1}\right)\end{array}$} & \multicolumn{2}{|c|}{ Organic diet } & \multirow[b]{2}{*}{$\mathrm{i}$} & \multirow{2}{*}{$\begin{array}{c}\mathrm{CR} \\
\left(1 \mathrm{~h}^{-1}\right)\end{array}$} & \multirow{2}{*}{$\begin{array}{c}\text { TFR } \\
\left(\mathrm{mg} \mathrm{h}^{-1}\right)\end{array}$} & \multirow{2}{*}{$\begin{array}{c}\text { OFR } \\
\left(\mathrm{mg} \mathrm{h}^{-1}\right)\end{array}$} & \multirow{2}{*}{$\begin{array}{l}\text { SE } \\
(\%)\end{array}$} & \multirow{2}{*}{$\begin{array}{c}\text { TIR } \\
\left(\mathrm{mg} \mathrm{h}^{-1}\right)\end{array}$} & \multirow{2}{*}{$\begin{array}{c}\text { OIR } \\
\left(\mathrm{mg} \mathrm{h}^{-1}\right)\end{array}$} & \multirow{2}{*}{$\begin{array}{l}\mathrm{AE} \\
(\%)\end{array}$} & \multirow{2}{*}{$\begin{array}{c}\mathrm{AR} \\
\left(\mathrm{mg} \mathrm{h}^{-1}\right)\end{array}$} \\
\hline & & $\left(\mathrm{mg} \mathrm{l}^{-1}\right)$ & $(\%)$ & & & & & & & & & \\
\hline \multicolumn{13}{|l|}{ Low } \\
\hline 24 & $3.93 \pm 0.11$ & $1.67 \pm 0.15$ & $42.49 \pm 2.77$ & 0.43 & $0.36 \pm 0.29$ & $14.28 \pm 1.15$ & $6.07 \pm 0.49$ & & $14.28 \pm 1.15$ & $6.07 \pm 0.49$ & $1.64 \pm 1$ & $3.74 \pm 0.30$ \\
\hline 72 & $3.93 \pm 0.11$ & $1.67 \pm 0.15$ & $42.49 \pm 2.77$ & 0.43 & $3.93 \pm 0.22$ & $15.44 \pm 0.85$ & $6.56 \pm 0.36$ & & $15.44 \pm 0.85$ & $6.56 \pm 0.36$ & $8.29 \pm 1$ & $3.82 \pm 0.21$ \\
\hline \multicolumn{13}{|l|}{ High } \\
\hline 24 & $20.8 \pm 2.81$ & $5.41 \pm 2.65$ & $26.01 \pm 2.52$ & 0.38 & $1.89 \pm 0.12$ & $39.36 \pm 2.54$ & $10.24 \pm 0.66$ & $.45 \pm 0.0$ & $13.72 \pm 2.54$ & $5.17 \pm 0.96$ & $7.78 \pm 2$ & $2.47 \pm 0.46$ \\
\hline 72 & $20.8 \pm 2.81$ & $5.41 \pm 2.65$ & $26.01 \pm 2.52$ & 0.38 & $1.97 \pm 0.18$ & $40.97 \pm 3.54$ & $10.69 \pm 1.02$ & $.47 \pm 0.0$ & $15.39 \pm 3.54$ & $5.89 \pm 1.35$ & $2.90 \pm 1$ & $3.11 \pm 0.79$ \\
\hline
\end{tabular}

i, organic fraction of food ingested; CR, clearance rate; TFR, total filtration rate; OFR, organic filtration rate; SE, selection efficiency; TIR, total ingestion rate; OFR, organic filtration rate; SE, selection efficiency; TIR, total ingestion rate; OIR, organic ingestion rate; AE, absorption efficiency; AR, absorption rate. 

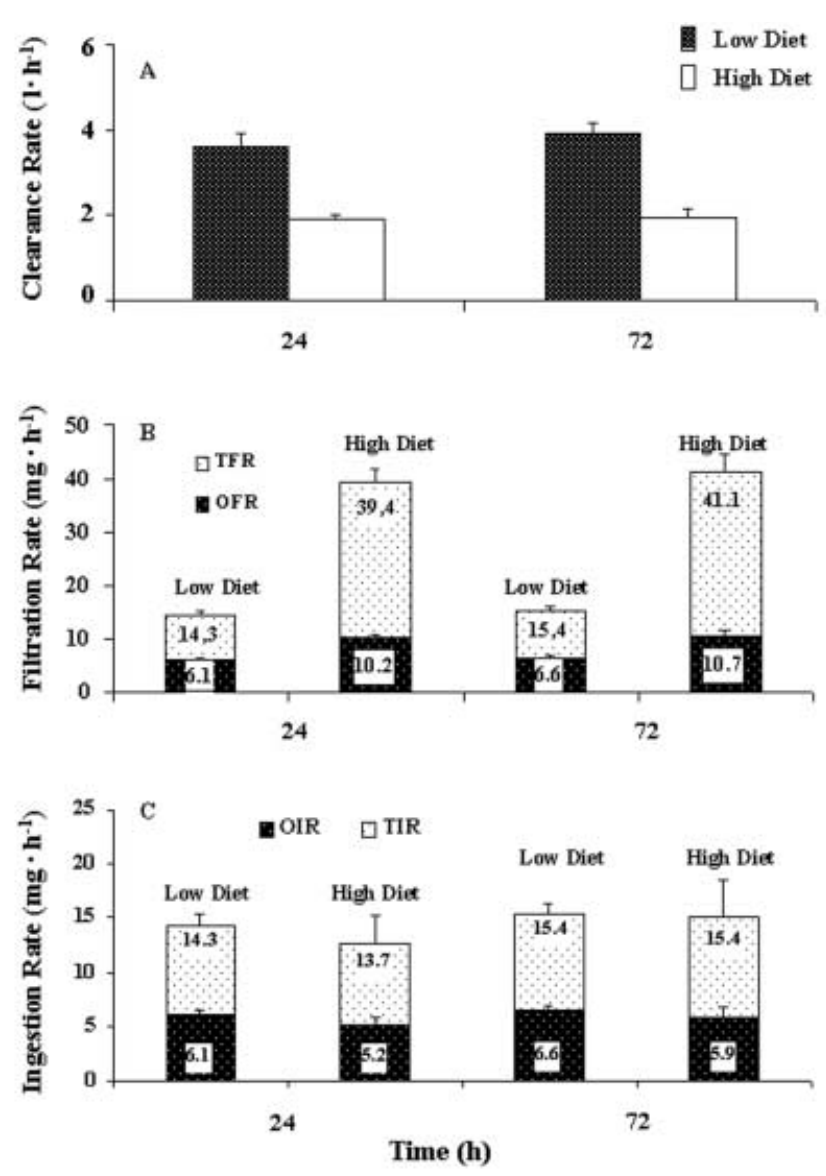

Figure 1. Argopecten purpuratus: (A) clearance rate; (B) total (TFR) and organic (OFR) filtration rates; and (C) total (TIR) and organic (OIR) ingestion rates in relation to different diets and conditioning times. Values are means \pm SE.
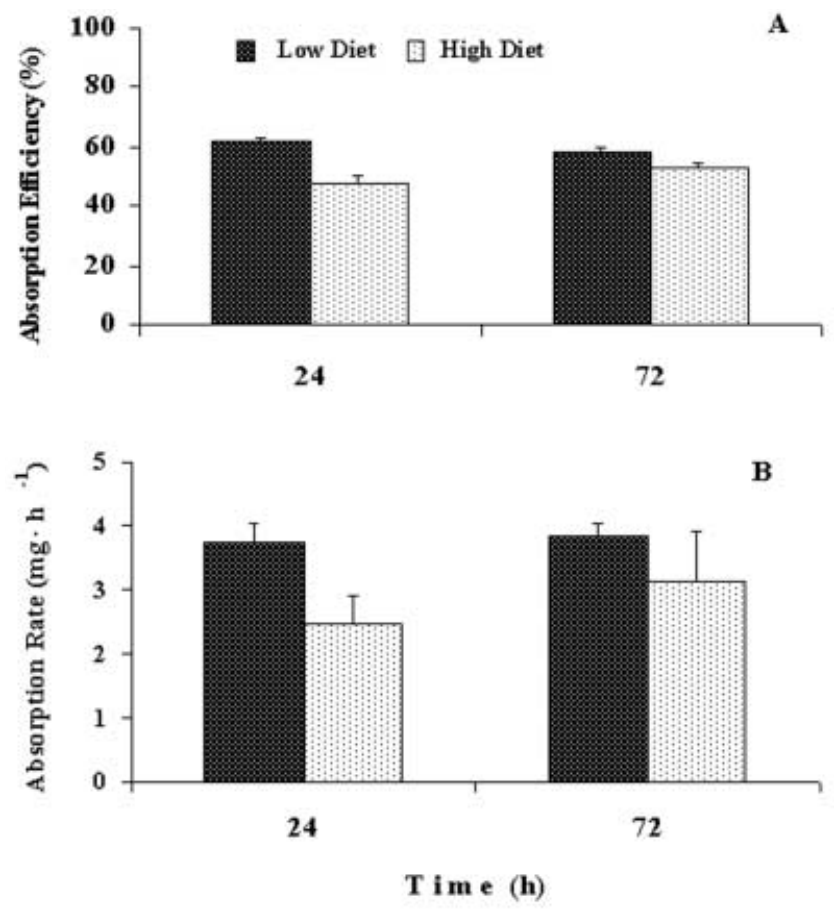

Figure 2. Argopecten purpuratus: (A) absorption efficiency; and $(\mathrm{B})$ absorption rate, in relation to different diets and conditioning times. Values are means $\pm \mathrm{SE}$.

\section{Statistical analyses}

One-way analysis of variance (ANOVA) was performed, followed by a Tukey test of significance in order to examine possible differences among the physiological rates associated with diets and acclimation times. Two-way ANOVA was performed to estimate the degree of association among the physiological rates and the variables of time and diet. Statistical analyses were carried out using the Statistica v $4.0^{\circledR}$ program at a significance level of 0.05 .

\section{RESULTS \\ Physiological rates}

Diets used in the physiological measurements were significantly different from one another, both in quantity $\left(3.93 \mathrm{mgl}^{-1}\right.$ vs $\left.20.80 \mathrm{mgl}^{-1}\right)$ and in quality $(42.5 \%$ vs $26.0 \%$ organic matter) as shown in Table 1 . The one-way ANOVA showed that the clearance rate of Argopecten purpuratus was similar over different time periods measured, without significant differences $(P>0.05)$ at either of the two food concentrations (Table 1; Figure 1A). Clearance rate became significantly reduced from $3.93 \mathrm{l} \mathrm{h}^{-1}$ with the low diet $(72 \mathrm{~h})$ to $1.89 \mathrm{lh}^{-1}$ with the high diet. The two-way ANOVA showed that only the diet factor had a significant effect on the CR, explaining $51.7 \%$ of the variance (Table 2 ).

The filtration rate was also unaffected by the time factor $(P>0.05)$ with both experimental diets (Figure $1 \mathrm{~B})$. The diet produced a significant effect $(P \leqslant 0.05)$ with an almost threefold increase when $A$. purpuratus was exposed to the highest food concentration (Table 1; Figure 1B). Thus diet alone explained $85.5 \%$ of the variance of the total filtration rate. Organic filtration rate followed a similar pattern where diet alone explained $55.5 \%$ of the variance (Figure 1B).

Production of pseudofaeces only occurred when $A$. purpuratus was fed with the high diet. The time factor had no significant effect $(P>0.05)$ on the production of pseudofaeces and the material eliminated as pseudofaeces reached a value of $25.64 \mathrm{mgh}^{-1}(65.1 \%$ of filtered material) at $24 \mathrm{~h}$, and $25.70 \mathrm{mg} \mathrm{h}^{-1}(62.5 \%$ of filtered material) at $72 \mathrm{~h}$. The organic content of the pseudofaeces varied between $15.8 \%$ and $20.4 \%$, with both values significantly lower $(P \leqslant 0.05)$ than the organic content of the diet offered. This suggested that $A$. purpuratus had the capacity for preferential selection of organic over inorganic particles for ingestion. Based on the relation between the organic fraction of the food and the pseudofaeces, it was estimated that $A$. purpuratus exposed to a diet of $20.80 \mathrm{mgl}^{-1} \quad(\mathrm{f}=0.26)$ showed a pre-ingestive selection efficiency of $45 \%$ at $24 \mathrm{~h}$ and $47 \%$ at $72 \mathrm{~h}$ (Table 1 ). These results were also unaffected by the time factor $(P>0.05)$. The organic content of the filtered food at the high diet was $26.01 \%$, while through efficiency of particle selection for organic matter, the ingested material increased to values of $37.7 \%$ and $38.2 \%$ at 24 and $72 \mathrm{~h}$, respectively. The two-way ANOVA showed that the factors time and diet, as well as the interaction of these, had no significant effects $(P>0.05)$ on the total and OIRs (Table 2; Figure 1C). 
Table 2. Two way ANOVA testing physiological variables in Argopecten purpuratus.

\begin{tabular}{|c|c|c|c|c|c|}
\hline Source & Sum of square & df & Mean square & $F$ ratio & $P$ \\
\hline \multicolumn{6}{|l|}{ Clearance rate } \\
\hline Time & 0.329 & 1.0 & 0.329 & 0.453 & 0.505 \\
\hline Diet & 30.724 & 1.0 & 30.724 & 42.324 & 0.000 \\
\hline Time $\times$ diet & 0.100 & 1.0 & 0.100 & 0.137 & 0.713 \\
\hline Error & 28.311 & 39.0 & 0.726 & & \\
\hline \multicolumn{6}{|l|}{ Filtration rate } \\
\hline Time & 15.905 & 1.0 & 15.905 & 0.706 & 0.406 \\
\hline Diet & 4.885 & 1.0 & 4.885 & 216.912 & 0.000 \\
\hline Time $\times$ diet & 0.614 & 1.0 & 0.614 & 0.027 & 0.870 \\
\hline Error & 833.342 & 37.0 & 22.523 & & \\
\hline \multicolumn{6}{|c|}{ Organic filtration rate } \\
\hline Time & 1.693 & 1.0 & $1,693.000$ & 0.608 & 0.440 \\
\hline Diet & 130.673 & 1.0 & 130.673 & 46.943 & 0.000 \\
\hline Time $\times$ diet & 0.004 & 1.0 & 0.004 & 0.001 & 0.971 \\
\hline Error & 102.994 & 37.0 & 2.784 & & \\
\hline \multicolumn{6}{|c|}{ Absorption efficiency } \\
\hline Time & 5.066 & 1.0 & 5.066 & 0.268 & 0.609 \\
\hline Diet & 600.756 & 1.0 & 600.756 & 31.822 & 0.000 \\
\hline Time $\times$ diet & 116.405 & 1.0 & 116.405 & 6.166 & 0.021 \\
\hline Error & 434.213 & 23.0 & 18.879 & & \\
\hline \multicolumn{6}{|c|}{ Absorption rate } \\
\hline Time & 1.007 & 1.0 & 1.007 & 0.887 & 0.352 \\
\hline Diet & 7.417 & 1.0 & 7.417 & 6.538 & 0.015 \\
\hline Time $\times$ diet & 0.593 & 1.0 & 0.593 & 0.523 & 0.474 \\
\hline Error & 41.972 & 37.0 & 1.134 & & \\
\hline \multicolumn{6}{|l|}{ Ingestion rate } \\
\hline Time & 15.319 & 1.0 & 15.319 & 0.680 & 0.415 \\
\hline Diet & 0.696 & 1.0 & 0.696 & 0.031 & 0.861 \\
\hline Time $\times$ diet & 0.503 & 1.0 & 0.503 & 0.022 & 0.882 \\
\hline Error & 833.358 & 37.0 & 22.523 & & \\
\hline \multicolumn{6}{|c|}{ Organic ingestion rate } \\
\hline Time & 2.762 & 1.0 & 2.762 & 0.758 & 0.390 \\
\hline Diet & 4.673 & 1.0 & 4.673 & 1.282 & 0.265 \\
\hline Time $\times$ diet & 0.090 & 1.0 & 0.090 & 0.025 & 0.876 \\
\hline Error & 134.897 & 37.0 & 3.646 & & \\
\hline
\end{tabular}

The one-way ANOVA showed that absorption efficiency was significantly higher $(\sim 60 \%)$ with the low diet (Table 1; Figure 2A). The two-way ANOVA did not show any significant effect of the time factor on this process. In contrast, the diet $(52.0 \%)$ and the time/diet interaction $(10.1 \%)$ showed a significant effect $(P \leqslant 0.05)$ on the absorption efficiency. In the case of the absorption rate, the one-way ANOVA indicated the existence of significant differences between the diets, with higher values with the low diet (Table 1; Figure 2B). The two-way ANOVA indicated that only the diet had a significant effect, explaining $14.6 \%$ of the variability for this process.

\section{DISGUSSION}

Argopecten purpuratus was exposed to short term variations in available food (quantity and quality) simulating natural environmental events (e.g. initiation and termination of phytoplankton blooms, resuspension of sediments due to tidal effects) occurring in the bays of southern Chile (Navarro et al., 1993). Bivalve filter feeders may show different responses to changes in quantity and quality of the food supply, depending on the time scale selected. The present results suggest that $A$. purpuratus is capable of modifying its feeding response to environmental conditions of high turbidity typical of those occurring in the environment during given seasons of the year such as tidal resuspension and sporadic storms. The response in which this scallop increases its $\mathrm{CR}$ at low seston concentrations $\left(3.93 \mathrm{mgl}^{-1}\right)$ has previously been described for other species as a typical behaviour reflecting a physiological strategy for maximization of energy uptake in environments with limited food availability (Willows, 1992). In contrast, the reduction in GR with an increase in suspended food represents a functional response in agreement with the review of Bayne \& Newell (1983) who described the ability of bivalve filter feeders to regulate the ingestion rate in the presence of high seston concentrations. Although there was no significant effect of the time factor on the quantity of food filtered by $A$. purpuratus, the high diet produced an increase in the amount of material filtered given that the CR was not reduced to a level enough to maintain a filtration rate independent of the food concentration. This behaviour has been related to an exploitive response of some species (Willows, 1992) for use (ingestion) of a greater quantity of organic material from the seston by means of a pre-ingestive selection mechanism. This response has also been 
described for Mytilus edulis (Bayne \& Hawkins, 1990) and Mytilus chilensis (Velasco \& Navarro, 2002), where it was concluded that there was an interactive effect between quantity and quality of the diet and the feeding behaviour of the bivalves. Thus the increase in filtration rate appears to be an efficient mechanism for optimization of energy gain in environments having high loads of low-quality seston. The high selection efficiency of particle observed in $A$. purpuratus at the high diet $\left(20.8 \mathrm{mgl}^{-1}\right)$ was similar to those described for Mytilus chilensis and Mulinia edulis by Velasco \& Navarro (2002) for similar seston concentrations. Based on this high capacity for particle selection at the pre-ingestive level, $A$. purpuratus was capable of compensating for the differences in food quality of the experimental diets and ingesting particulate material containing $38 \%$ organic matter as a result of the selection process when fed the high diet. The material ingested using the high diet was, however, absorbed with less efficiency than the low diet $(P<0.05)$ suggesting that the sediment incorporated in the high diet contained refractory organic material which was difficult to digest. This helps explain why $A$. purpuratus is a subtidal epibenthic species which occurs in natural habitats of low turbidity where resuspension of bottom sediment rarely occurs. The results also indicate that the experimental time of $72 \mathrm{~h}$ was not sufficient to acclimate its digestive response to a food supply significantly different from that of its habitat of origin, both with regard to quality and quantity. This would be related to the adjustment of the amount of metabolic faecal losses as the basis for digestive acclimation to reduced quality of food. The preceding explains the significant differences between the absorption rates of organic material between the two diets, allowing the conclusion that from the ecological perspective, habitats into which $A$. purpuratus is being introduced in the south of Chile are not favourable for energy gain in this species due to the frequent events of sediment resuspension in these areas. This conclusion is based on the facts that the main variability in the quantity and quality of the seston in southern Chilean bays occurs in scales of hours, due to sediment resuspensions caused by tidal changes and storms. Cranford (1995) also found a decrease in the absorption efficiency of non-acclimated (day 1) individuals of the scallop Placopecten magellanicus, concluding that when exposed to conditions of resuspension of sediments in amounts of $10 \mathrm{mgl}^{-1}, \quad P$. magellanicus demonstrated complete acclimation of its absorption efficiency after six days. Absorption efficiency and absorption rate did appear to be rising at $72 \mathrm{~h}$, suggesting that different results might be expected after longer periods of acclimation of $A$. purpuratus with the low quality, high quantity diet.

The results of the present study coincide with the general perspective in the sense that phytoplankton form the principal nutritional source for epibenthic suspension feeding species, and that resuspended detritus, although occurring in large quantities, may only be of importance once digestive processes become acclimated to processing them, and otherwise would be unable to deliver the energy required by the species.

We thank G. Urrutia (UACH-Chile) and B. Gonzalez and L. Nieto (CSIC-Espanã) for technical assistance. Thanks are also due to the Programa de Cooperación Cientifica Internacional CONICYT/CSIC grant no. 20023 212/2003CL0030, Chile y MICYT. REN2001-0501/MAR, España.

\section{REFERENCES}

Bayne, B.L. \& Hawkins, A.J.S., 1990. Filter feeding in bivalve molluscs: controls on energy balance. In Animal nutrition and transport processes. 1. Nutrition in wild and domestic animals. Vol. 5. Comparative physiology (ed. J. Mellinger et al.), pp. 70-83. Basel: Karger.

Bayne, B.L., Hawkins, A.J.S. \& Navarro, E., 1987. Feeding and digestion by the mussel Mytilus edulis L. (Bivalvia: Mollusca) in mixtures of silt and algal cells at low concentrations. Fournal of Experimental Marine Biology and Ecology, 111, 1-22.

Bayne, B.L. \& Newell, R.C., 1983. Physiological energetics of marine molluscs. In The mollusca. Vol. 4. Physiology (ed. A.S.M. de Saleuddin and K.M. Wilbur), pp. 407-515. New York: Academic Press.

Conover, R.J., 1966. Assimilation of organic matter by zooplankton. Limnology and Oceanography, 11, 338-345.

Cranford, P.J., 1995. Relationships between food quantity and quality and absorption efficiency in sea scallops Placopecten magellanicus (Gmelin). Fournal of Experimental Marine Biology and Ecology, 189, 123-142.

Iglesias, J.I.P., Navarro, E., Alvarez, P.J. \& Armentia, Y., 1992. Feeding, particle selection and absorption in cockles Cerastoderma edule (L.) exposed to variable conditions of food concentration and quality. Journal of Experimental Marine Biology and Ecology, 162, 177-198.

Kiørboe, T. \& Møhlenberg, F., 1981. Feeding, particle selection in suspension-feeding bivalves. Marine Ecology Progress Series, 5, 291-296.

Navarro, J.M., Clasing, E., Urrutia, G., Asencio, G., Stead, R. \& Herrera, C., 1993. Biochemical composition and nutritive value of suspended particulate matter over a tidal flat of Southern Chile. Estuarine, Coastal and Shelf Science, 37, 59-73.

Strickland, J.D.H. \& Parsons, T.R., 1972. A practical handbook of seawater analysis, 2nd. edn. Bulletin of the Fisheries Research Board of Canada, 167-310.

Velasco, L.A. \& Navarro, J.M., 2002. Feeding physiology of infaunal (Mulinia edulis) and epifaunal (Mytilus chilensis) bivalves under a wide range of concentration and quality of seston. Marine Ecology Progress Series, 240, 143-155.

Ward, J.E. \& MacDonald, B.A., 1996. Pre-ingestive feeding behaviors of two sub-tropical bivalves (Pinctada imbricata and Arca zebra): responses to an acute increase in suspended sediment concentration. Bulletin of Marine Science, 59, 417-432.

Willows, R.I., 1992. Optimal digestive investment: a model for filter feeders experiencing variable diets. Limnology and Oceanography, 37, 829-847.

Submitted 20 May 2003. Accepted 12 May 2004. 